\title{
ПОИСКИ НОВЫХ ПОДХОДОВ К СОЦИОКУЛЬТУРНОЙ ИНТЕГРАЦИИ МИГРАНТОВ
}

\author{
ИРИНАЦАПЕНКО
}

\begin{abstract}
Статья посвящена анализу основных направлений ведущихся государствами глобального Севера поисков эффективных подходов к управлению культурным разнообразием. Показано, что массовая иммиграция с глобального Юга резко усложняет культурную неоднородность принимающих обществ Севера. Последняя, в свою очередь, сопряжена с серьезными вызовами размывания их культурной идентичности, фрагментации и социально-политической дестабилизации, усиленными недавним миграционным кризисом. Угрозы дальнейшего расширения ареалов расселения и укрепления позиций выходцев из исламских стран в Европе сплетаются с рисками ее "рехристианизаџии» представителями южных течений христианства и распространения архаичных иенностей $u$ практик. Доминирование белого населения европейского происхождения в США все заметнее ослабляется быстро укрупняюшимися инокультурными сообществами выходцев из стран Латинской Америки и Азии. Ни ассимиляционизм, игнорирующчй и подавляющий культурные различия, ни сменивший его мультикультурализм, признающий и поощряющий их, не смогли дать эффективного ответа на рост разнообразия и помочь избежать усиления территориальной сегрегации, культурной замкнутости «параллельных сообществ» и сочиального иждивенчества их членов. На волне критики мультикультурализма вновь возрождается ассимиляционньй подход. В то же время предлагаются и новые интеграционные конщепты. Омникультурализм акцентирует общность человеческой природы разных этнорасовых групп, а поликультурализм - пересечение их историй и взаимосвязи, однако практическая реализаџия обоих подходов может иметь лишь ограниченный и спорный эффект. Интеркультурализм, делающий ставку на перенастройку городской системы управления и общественных структур на функционирование в условиях разнообразия и налаживание снизу конструктивного межкультурного взаимодействия, уже позитивно себя зарекомендовал в локальных практиках. Вместе с тем результаты таких инициатив пока скромны и непрочны. Это делает перспективы интеркультурализма неопределенными, пока он не пройдет проверку на национальном уровне.
\end{abstract}

Ключевые слова: иммиграџия, этнокультурное разнообразие, ассимиляционизм, мультикультурализм, новая политика гражданской интеграции, омникультурализм, поликультурализм, интеркультурализм.

\section{ВВЕДЕНИЕ}

Вопрос о том, как адекватно организовать этнокультурное разнообразие и обеспечить при его сохранении гражданское единство и согласие в многорелигиозной, многорасовой и многоэтничной нации, выдвинулся в число ключевых, жизненно важных, по сути, экзистенциальных для современных обществ. И решение этого вопроса во многом зависит от выбора и реализация верной интеграционной стратегии.

ИРИНА ПАВЛОВНА ЦАПЕНКО (tsapenko@bk.ru), НАЦИОНАЛЬНЫЙ ИССЛЕДОВАТЕЛЬСКИЙ ИНСТИТУТ МИРОВОЙ ЭКОНОМИКИ И МЕЖДУНАРОДНЫХ ОТНОШЕНИЙ ИМ. Е.М. ПРИМАКОВА РАН (ИМЭМО РАН), РОССИЯ.

СТАТЬЯ ПОДГОТОВЛЕНА ПРИ ПОДДЕРЖКЕ РФФИ, ПРОЕКТ №16-07-0ООО8-ОГН-А «ИНТЕГРАЦИЯ ИНОКУЛЬТУРНЫХ МИГРАНТОВ: ПЕРСПЕКТИВЫ ИНТЕРКУЛЬТУРАЛИЗМА» .

СТАТЬЯ ПОСТУПИЛА В РЕДАКЦИЮ В СЕНТЯБРЕ 2018 Г. 
Анализу основных направлений поисков, ведущихся уже не одно десятилетие государствами глобального Севера в области эффективных подходов к социокультурной интеграции мигрантов, посвящена предлагаемая статья. В работе предпринята попытка показать главные причины современного кризиса интеграционной политики, представить новые концепты сближения представителей разных этносов и культур и оценить имплементационные возможности предлагаемых подходов к организации межкультурного взаимодействия. Логика решения этих задач определяет структуру исследования. В контексте рассмотрения этнокультурных сдвигов, порожденных иммиграцией, обозначаются вызовы разнообразия, требующие адекватного ответа принимающих государств. При характеристике ассимиляционизма и мультикультурализма выделяются как преимущества этих интеграционных парадигм, обеспечившие их долговечность, так и ограничения, обусловившие необходимость смены данных моделей. В качестве новых концептов сближения разных культур анализируются омникультурализм, поликультурализм и интеркультурализм. Теоретическим основаниям и практикам интеркультурализма как наиболее вероятной альтернативе прежним подходам уделяется особое внимание. Автор не сводит политику интеркультурализма сугубо к реализации европейского проекта «Межкультурные города» и тем более к таким «витринным» инициативам, как межэтнические семейные чаепития. Интеркультурализм представляется как объемлющий интеграционный курс, опирающийся на практики, которые возникли задолго до запуска данного проекта, и имеющий по сравнению с последним гораздо более широкое территориальное распространение.

Исследование опирается на статистические данные ООН, Бюро переписи населения США, Исследовательского центра Pew, Евробарометра, Европейского статистического исследования и др.

\section{ЭТНОКУЛЬТУРНЫЕ ПОСЛЕДСТВИЯ ИММИГРАЦИИ}

По данным ООН, 61\% мигрантов, проживавших в 2017 г. в развитых регионах мира, были уроженцами развивающихся регионов ${ }^{1}$ [UN 2017]. Массовая иммиграция с глобального Юга несет странам Севера многомерные и неоднозначные последствия. Важнейшие из них - радикальные изменения в этнической, лингвистической, конфессиональной и других композициях принимающих обществ, умножающие пестроту мозаики культурных идентичностей этих социумов, особенно в крупных городах. К примеру, в Амстердаме, Роттердаме и Гааге проживают представители свыше 170 этнонациональных групп; жители Торонто говорят более чем на 140 разных языках и диалектах.

Немецкий культуролог С. Вертовек квалифицирует этнокультурные сдвиги в развитых регионах мира как “трансформирующую диверсификацию разнообразия" (transformative diversification of diversity). Возникающее в результате этого сверхразнообразие (super-diversity) означает «не только усложнение состава населения по

\footnotetext{
${ }^{1}$ Согласно классификации ООН, к развитым регионам относятся страны Северной Америки и Европы, а также
} Австралия, Новая Зеландия и Япония, к развивающимся - все остальные государства. 
этносам и странам происхождения, но и ... возникновение новых взаимосвязей и взаимодействий» [Vertovec 2007: 1025].

Так, иммиграция, привнося извне разнообразие этнических, конфессиональных, лингвистических и других идентичностей, способствует конструированию его новых, все более многоликих форм и изнутри принимающего общества. Поскольку зачастую мигранты не утрачивают своих исторических корней, прежней культуры, происходит смешение и объединение элементов взаимодействующих культур и возникновение новых культурных феноменов. В такой среде обитания на границах и перекрестках разных культур генерируются новые транскультурные пластичные самокатегоризации [Berry, Epstein 2005: 25], в которые заложен интеграционный потенциал. По результатам обследования 2015 г. только 32\% испаноамерикацев первого поколения, родившихся за пределами США, были билингвальными и лишь 7\% предпочитали английский язык, у представителей второго поколения эти показатели составляли уже 51 и 43\%, а у третьего и последующих 24 и 75\% соответственно. Аналогичным образом считали себя хиспэникс 97\% уроженцев Латинской Америки, 92\% мигрантов во втором поколении, 77\% - в третьем и 50\% - в четвертом и последующих [Lopez, Gonzalez-Barrera, Lypez 2017]. А ослаблению лингвистической составляющей идентичности испаноговорящих групп сопутствовала американизация их этнорасового самоопределения.

В то же время интенсивное разрастание сообществ представителей незападных этносов и цивилизационных принадлежностей благоприятствует устойчивости маркерных черт присущей им отличной культуры повседневности, системы ценностей и самоидентификации. В соответствии с идеей третьего демографического перехода, выдвинутой британским демографом Д. Коулменом, в условиях ухудшения демографической ситуации в государствах Севера, прежде всего Европы, идет замещение исконного населения быстро увеличивающимися чужеродными диаспорами и наступление их инокультурных идентичностей.

В Западной Европе, особенно во Франции, Германии и Великобритании, возникли крупные общины уроженцев стран исламского Юга. В 2016 г. численность мусульман в 28 странах ЕC, Норвегии и Швейцарии оценивалась центром Pew в 25,8 млн (4,9\% населения). Такие оценки представляют собой довольно сложную задачу, основаны на ряде допущений и поэтому не могут рассматриваться как абсолютно достоверные, хотя представление о порядке величин они все же, видимо, дают. Эту оговорку необходимо учитывать при всех последующих рассуждениях, касающихся нынешнего или прогнозируемого центром Pew числа мусульман в Европе.

Быстрому росту мусульманских диаспор способствует преобладание выходцев из исламских стран в миграционных, в первую очередь вынужденных, потоках. В результате в 2010-2016 гг. нетто-миграция мусульман составила 3,5 млн, существенно опередив соответствующий показатель немусульман - всего 1,3 млн [Pew... 2017: 2]. Механический прирост мусульманского населения в свою очередь ускоряет и без того его высокую естественную динамику, определяемую молодостью мигрантов из исламских стран, их высоким репродуктивным потенциалом и традициями многодетности. При том, что в 2016 г. медианный возраст мусульманского населения в Европе составлял 30 лет (в том числе во 
Франции - 27 лет, Великобритании - 28 лет), у жителей региона, не связанных с исламской традицией, -44 года. В среднем, коэффициент суммарной рождаемости связанных с этой традицией женщин в Европе достигал 2,6 (3,1 в Финляндии, 2,9 во Франции и Великобритании, 2,8 в Швеции), тогда как у остальных он составлял всего 1,6 (в Греции 1,3). В результате в 2010-2016 гг. естественный прирост населения, оказавшегося в Европе в результате миграции из регионов преобладания ислама, составил 2,9 млн, тогда как остальное население региона понесло естественную убыль 1,7 млн человек [Pew... 2017: 5, $12,34,37]$.

Во всех сценариях прогнозов исследовательского центра Pew ожидается рост численности мусульман в Европе - более динамичный, чем других групп населения. К 2050 г. при сценарии нулевой миграции численность населения, связанного с исламской традицией, в регионе возрастет до 35,8 млн (7,4\% населения); при средней миграции продолжении так называемых регулярных потоков (трудовых, учебных, семейных), но прекращении приема беженцев - до 57,9 млн (11,2\%); при высокой миграции - сохранении всех паттернов миграции 2014-2016 гг. - до 75,6 млн (14\%) [Реw... 2017: 5]. В последнем случае абсолютная и относительная численность мусульман и их потомков в регионе утроится. В частности, при высокой миграции к 2050 г. численность мусульман превысит 17 млн в Германии и 13 млн в Великобритании и Франции [Реw... 2017: 29]. А их доля в Швеции может достичь 31\%, Германии и Австрии - 20\%, Франции и Бельгии - $18 \%$. В странах Северной и Центральной Европы удельный вес приверженцев ислама возрастет более чем на 10 п.П., в том числе в Швеции - на 22.4 п.п., что несет серьезные риски социальных катаклизмов на этнокультурной почве (таблица).

Наряду с рисками «исламизаџии» в последние годы обозначились и угрозы «рехристианизации» Европьл афрохристианами и связанные с этим вызовы сложившейся западной культурной идентичности, которые обусловлены массовыми потоками туда мигрантов из прохристианских стран Тропической Африки, сохраняющих черты традиционных обществ с присущей им значимой ролью общинности в организации жизни, ритуалов и др. В 2017 г. в Европе проживало 4,15 млн уроженцев этих государств (на 420 тыс. больше, чем в 2010 г.), в том числе 1,27 млн в Великобритании, 980 тыс. Франции, 370 тыс. - Италии и 360 тыс. - в Португалии (для сравнения: в США в 2017 г. проживало 1,55 млн выходцев из этих стран) [Pew... 2018: 3, 6, 8].

Как верно подмечает Л. Андреева, миграционные потоки «южных христиан из стран к югу от Сахары в Европу (как и мусульман) несут архаизацию не только современному европейскому христианству, но и самой секулярной европейской цивилизации. При том что, с одной стороны, в Европе доминируют секулярные ценности и христианство по сути стало элементом культуры, а с другой - нормы афрохристианства являются подлинно религиозными, встреча «северного» и «южного» христианства в условиях чуждого для афрохристианства современного европейского цивилизационного кода выльется в противоборство цивилизационных ценностей постиндустриального общества и архаических ценностей» [Андреева 2018]. 
Таблица. Прогнозные сценарии динамики доли мусульман в населении некоторых европейских стран, \%

\begin{tabular}{l|r|r|c|c|c}
\hline & 2010 & 2016 & $\begin{array}{c}2050 \\
\text { нулевая } \\
\text { миграция }\end{array}$ & $\begin{array}{c}2050 \\
\text { средняя } \\
\text { миграция }\end{array}$ & $\begin{array}{c}2050 \\
\text { высокая } \\
\text { миграция }\end{array}$ \\
\hline $\begin{array}{l}\text { Группа стран ЕС-28, Норвегии } \\
\text { и Швейцарии в целом, }\end{array}$ & 3,8 & 4,9 & 7,4 & 11,2 & 14,0 \\
$\begin{array}{l}\text { в том числе: } \\
\text { Кипр }\end{array}$ & 25,3 & 25,4 & 25,5 & 26,6 & 28,3 \\
Швеция & 4,6 & 8,1 & 11,1 & 20,5 & 30,6 \\
Франция & 7,5 & 8,8 & 12,7 & 17,4 & 18,0 \\
Великобритания & 4,7 & 6,3 & 9,7 & 16,7 & 17,2 \\
Бельгия & 6,0 & 7,6 & 11,1 & 15,1 & 18,2 \\
Норвегия & 3,7 & 5,7 & 7,2 & 13,4 & 17,0 \\
Нидерланды & 6,0 & 7,1 & 9,1 & 12,5 & 15,2 \\
Италия & 3,6 & 4,8 & 8,3 & 12,4 & 14,1 \\
Дания & 4,0 & 5,4 & 7,6 & 11,9 & 16,0 \\
Финляндия & 1,2 & 2,7 & 4,2 & 11,4 & 15,0 \\
Германия & 4,1 & 6,1 & 8,7 & 10,8 & 19,7 \\
Австрия & 5,4 & 6,9 & 9,3 & 10,6 & 19,9 \\
Швейцария & 4,9 & 6,1 & 8,2 & 10,3 & 12,9 \\
Болгария & 11,1 & 11,1 & 12,5 & 9,2 & 11,6 \\
Греция & 5,3 & 5,7 & 6,3 & 8,1 & 9,7 \\
Испания & 2,1 & 2,6 & 4,6 & 6,8 & 7,2 \\
Ирландия & 1,1 & 1,4 & 1,6 & 4,3 & 4,4 \\
Португалия & 0,3 & 0,4 & 0,5 & 2,5 & 2,5 \\
Венгрия & 0,1 & 0,4 & 0,4 & 1,3 & 4,5 \\
\hline
\end{tabular}

Источник: [Pew... 2017: 30].

Под воздействием иммиграции происходят серьезные изменения и в этнокультурном портрете США. Белые американцы, потомки выходцев с Британских островов, из Германии и других европейских стран, составлявшие в 2016 г. 61,3\% населения страны, в 2060 г., хотя и останутся крупнейшей этнорасовой группой, но уже не будут большинством - их доля сократится до 44,3\% [Vespa, Armstrong, Medina 2018: 7-8]. Этот процесс вызван стремительным ростом населения латиноамериканского и азиатского происхождения.

На долю уроженцев Латинской Америки, в основном Мексики, приходится большинство населения иностранного происхождения и уже сформировалось весьма многочисленное сообщество так называемых хиспэникс (Hispanics), или латинос (Latinos), объединяемых общностью испанского языка, латиноамериканских корней и культуры. В 2016 г. испаноязычное меньшинство насчитывало 57 млн человек (17,8\% населения США, в том числе 48\% жителей штата Нью-Мексико и более 90\% в 2 крупных метрополисах), уступая лишь белому большинству. А в 2060 г., по прогнозам американского Бюро переписи населения (БПН), оно достигнет 111 млн (27,5\%) [Vespa, Armstrong, Medina 2018: 7], обеспечивая основную часть демографического прироста страны.

В то же время, при всей серьезности вызова испанизации, брошенного американскому обществу, все четче обозначаются тенденции его азиатизащии. Показатели среднегодового увеличения численности испаноязычных общин в США снижаются (с 5,8\% в 90-е годы и 4,4\% в 2000-2007 гг. до 2,8\% в 2007-2014 гг.), отдавая первенство более 
динамичному укрупнению азиатских сообществ (3,4\% в 2007-2014 гг.) [Stepler, Lopez 2016]. По оценкам БПН, за 2016-2060 гг. доля азиатов в населении увеличится с 5,7 до 9,1\%, а среди проживающих в США уроженцев других стран - с 27,2 до 28,2\% при том, что аналогичная доля латинос сократится с 44,8 до 39,3\% [Vespa, Armstrong, Medina 2018: 7].

Демографическая и социокультурная экспансия этнических меньшинств усиливает риски фрагментации и поляризации многосоставных социумов. Этнополитические размежевания на «своих-чужих» усугубляются социально-экономической дифференциацией последних, этнизацией таких острых социальных проблем принимающих обществ, как безработица, бедность, депривация, социальное неравенство, геттоизация городского пространства и др. ${ }^{2}$ Это в свою очередь способствуют воспроизводству и укреплению культурной обособленности таких «параллельных миров» и обусловливает насущную потребность принимающих государств в адекватной интеграционной политике.

\section{АССИМИЛЯЦИОННЫЙ И МУЛЬТИКУЛЬТУРАЛИСТСКИЙ ПОДХОДЫ К ИНТЕГРАЦИИ МИГРАНТОВ: ПРИЧИНЫ НЕУДАЧ}

В развитых регионах мира наибольшее распространение получили две парадигмы интеграционной политики. Во-первых, это ассимиляционный курс на стирание этнокультурной неоднородности принимающего общества, который опирается на так называемый этнический дальтонизм, не различающий цвета кожи (colour-blind) и формально считающий равными разные расы и этносы. И, во-вторых, мультикультуралистская стратегия признания этнокультурного разнообразия и создания условий для его поддержания.

Согласно первой парадигме этнорасовые предрассудки проистекают из неадекватного фокусирования общественного внимания на групповых принадлежностях и могут быть ослаблены путем акцентирования общности черт представителей разных этнорасовых групп, их принадлежности к одной нации или необходимости принятия всеми группами господствующей культуры мейнстрима [Rosenthal, Levy 2010]. Это, по сути, означает ассимиляцию, основными теоретиками «классического варианта» которой являются М. Гордон, Р. Альба и В. Ни. Такой тип интеграции предполагает одностороннее усвоение переселенцами социальных нормативов относительно гомогенного принимающего общества и полную утрату представителями меньшинств своей этнокультурной самобытности. Яркие образцы подобной политики представляли Франция и США.

Во Франции согласно модели гражданской интегращии государство обязано обеспечить иммигранту благоприятные условия для быстрого получения гражданства

\footnotetext{
${ }^{2}$ Согласно опросу Центра Pew, в 2016 г. 47\% испаноязычных жителей отнесли себя к низшему классу по сравнению с 32\% англосаксонских, а к высшему классу - напротив 8 и 17\% соответственно; 52\% латинос сталкивались с дискриминацией или несправедливым отношением из-за их этнорасовой принадлежности [Pew... 2016: 59, 70]. Примерно 40\% жителей США, идентифицирующих себя как латинос, проживают в этнических анклавах [Lopez, Gonzalez-Barrera, Lypez 2017].
} 
принимающей страны. Из принципа равенства всех французских граждан перед законом вытекает требование политической лояльности стране и следования ее культурным нормам в публичной сфере. Этнические, культурные и религиозные вопросы относятся сугубо к сфере частной жизни мигрантов.

В США модель плавильного котла (melting pot) долгие годы выступала одним из главных принципов строительства этой нации иммигрантов. Данный курс предполагал «сплавление» населяющих страну народов, растворение их различий и формирование на этой основе американской национальной идентичности. Важная роль в процессе американизации отводилась языковой ассимиляции.

Однако, несмотря на ценность заложенного в подобный подход равенства отношения ко всем жителям как к гражданам, независимо от их культурной принадлежности, его реализация не предполагала активного противодействия расизму и дискриминации. Кроме того, как показывает исторический опыт, такой тип интеграции «работает», как правило, лишь в тех случаях, когда мигранты сравнительно не многочисленны, этнически относительно близки коренному населению и территориально распылены по стране. Ныне полная ассимиляция этнических меньшинств нереалистична по целому ряду причин. Главные из них:

- формирование весьма крупных диаспор представителей незападных цивилизаций;

- постоянный массовый приток инокультурных мигрантов, пополняющий такие сообщества новыми неинтегрированными контингентами:

- становящаяся критической территориальная концентрация приезжих и их потомков;

- их отличность от коренного населения;

- чужеродность для них культуры западного мира, в особенности трудная совместимость норм и ценностей традиционного ислама и христианского основания западной цивилизации;

- инертность их облика, маркера коллективной идентичности;

- большая длительность ассимиляционного процесса, порой растягивающаяся на несколько поколений;

- распространение «ксенорасизма» в принимающих обществах.

О пробуксовке ассимиляционного подхода к интеграционной политике, доминировавшего в западных странах вплоть до 70-х годов прошлого века, свидетельствовал продолжавшийся рост этнических анклавов и маргинализация мигрантов второго и третьего поколений. Более того, в США не только не удалось воспрепятствовать расширению испаноязычных ареалов, но и сохранились тенденции к сегрегации афроамериканцев в пространственных гетто и экономических нишах. Недовольство представителей этнических меньшинств своим депривированным, маргинальным положением проявлялось в социальных волнениях, периодически вспыхивающих в негритянских кварталах городов США.

Вслед за кризисом ассимиляционной стратегии в 70-90-е годы утвердилась вторая парадигма - мультикультурализма, активными сторонниками которого являются У. Кимлика, Б. Парекх, Ч. Тейлор, Т. Модуд и др. В основе мультикультуралистской 
концепции интеграции лежит признание и регулирование культурного многообразия на основе принципов взаимности, равенства и сплоченности. Мультикультуралистская интеграционная политика в теории предполагала обеспечение большей проницаемости границ между культурами меньшинств и большинства и двусторонность, встречность интеграционного процесса.

Выделяются две главные разновидности мультикультуралистской политики.

Первый вариант - так называемой культурной мозаики - характерен для Канады, Австралии и Новой Зеландии, где мультикультурализм возведен в ранг национальной политики. В Канаде принцип культурного плюрализма стал основой нации и лозунгом национальной политики: «Одна нация, два языка, много народов и культур». В Австралии успешному встраиванию приезжих в принимающий социум помимо активной политики мультикультурализма благоприятствовала и местная культура, в которой мужское братство и товарищество (mateship) считаются отличительными чертами национального характера, олицетворяют солидарность и взаимопомощь и формируют толерантную интеграционную среду [Культурная сложность... 2016: 185].

Второй вариант - так называемый корпоративный мультикультурализм, воплощавшийся в Нидерландах и Великобритании. В Нидерландах по праву почвы всем родившимся там потомкам мигрантов предоставлялось гражданство этой страны и были адресованы социальные программы, обеспечивавшие доступ к образованию, жилому фонду и социальной помощи. Традиции защиты прав верующих и атеистов облегчили учреждение мусульманских и прочих учебных заведений конфессиональной направленности; введение квотной системы способствовало трудоустройству жителей с иностранными корнями и расширению их представительства в политических институтах и СМИ [Wood, Landry 2008: 59].

Власти Великобритании делали упор на поддержание общественного порядка и управление отношениями между большинством и меньшинствами, формируя правовые условия для искоренения дискриминации и побуждения государственных организаций к учету в их деятельности этнокультурого разнообразия общества. И такая политика продемонстрировала немало достоинств. Среди них - образовательные успехи небелых жителей, рост в их массе средних слоев, их активное участие в политической жизни, лояльность мусульман британской нации, поддержка ее внешнеполитического курса и др. [Культурная сложность... 2016: 87].

Однако во всех странах, проводивших политику мультикультурализма, наиболее сложные проблемы инкорпорации инокультурных сообществ так и остались нерешенными, а некоторые из них даже обострились. В Великобритании отсутствие масштабных мер по интеграции представителей меньшинств в сферу занятости и их социальной поддержке обернулось появлением новых этнических анклавов, стигматизируемых массовой безработицей и депривацией их жителей. И Австралии, и Голландии, и Великобритании не удалось избежать волнений и беспорядков на этнорасовой почве.

Причины неудач в построении многокультурного общества равных возможностей кроются как в сущности самой концепции мультикультурализма, так и в изменении условий 
ее практической реализации. Воплощение подобной модели, поощряющее сохранение унаследованных элементов культурной идентичности, не благоприятствует развитию чувства принадлежности к новой культуре. Как пишет известный российский этнолог Е.И. Филиппова, реализация указанной стратегии вызывает «постоянное воспроизводство и исключение "другого" внутри национального государства, создание внутренних границ в форме этнических гетто и замкнутых общин... В конечном итоге идеология мультикультурализма, предполагающая примат культурного над социальным, и тем более политика мультикультурализма, ставящая групповые права выше индивидуального выбора, противоречат принципам демократии и угрожают существованию построенных на этих принципах национальных государств» [Филиппова 2014: 56-57].

Кроме того, представляется, что мультикультуралистский курс нациестроительства так же, как и феномен нации, - исторически преходящий феномен. Поскольку «мультикультурализм жизнеспособен при сильной поддержке чувства общности у граждан принимающей страны» [Культурная сложность... 2016: 87], разворачивающийся кризис национальной идентичности лишает этот курс необходимой опоры. Более того, местное население видит в «чужаках» угрозы для национальной идентичности и риски для безопасности принимающих стран, исходящие от множественной лояльности и соответственно политической ненадежности мигрантов. Подъем «взращенного в домашних условиях» исламского терроризма, равно как и экстремизма коренных белых жителей в отношении мусульман, уже не оставляет сомнений в провале мультикультурализма в Старом Свете. Даже в Австралии и Канаде ощущается все больше скепсиса относительно перспективности этого курса.

Надо также учитывать, что, как показывает пример Нидерландов, политика мультикультурализма проводилась в условиях ограниченного числа крупных мигрантских сообществ и основывалась на наделении их «дифференцированными по группам правами». При этом государство субсидировало самоорганизацию мигрантов, их обучение, радиовещание на их родных языках, их привлечение к политическим консультациям и др. Однако резкое усиление разнообразия населения принимающих стран существенно усложняет управление этим разнообразием и с организационной, и с финансовой точек зрения.

На волне критики мультикультурализма справа в Европе вновь возрождается первая парадигма, знаменуемая развертыванием «стратегии антиразнообразия» [Waal 2018]. Современный вариант ассимиляционизма получил название новой политики гражданской интеграции, активным теоретиком и сторонником которой выступает немецкий социолог Х. Йоппке [Joppke 2018]. При таком курсе делается акцент на занятости вновь прибывших, овладении ими базовыми знаниями языка, истории и институтов принимающей страны, уважении ими базовых либерально-демократических ценностей как непременных условиях для получения вида на ПМЖ и гражданства. При этом допускается применение санкционно-принудительных мер. Например, если мигранты уклоняются от посещения обязательных курсов по изучению языка, истории и институтов принимающей страны, допускается отказ властей в продлении им временного вида на жительство, уменьшение пособий и т.п. 
Однако, принуждение иммигрантов к ассимиляции, включая ограничение культурно-религиозных прав ${ }^{3}$, чревато социальным исключением, нарушением демократических принципов и подавлением культурного плюрализма. Более того, оно провоцирует сопротивление «реактивной этничности», способствуя акцентированию инокультурного маркера идентичности таких сообществ и их политической самоорганизации по этническому принципу. Указанные обстоятельства не позволяют рассматривать подобную стратегию как полноценную альтернативу прежним подходам.

Еще в 2005 г. Т. Филлипс, возглавлявший тогда британскую Комиссию по расовому равенству, заявил: «Над нами нависла угроза выплеснуть интеграционного младенца из купели вместе с ассимиляционной водой... Необходим баланс между "все дозволяющим" мультикультурализмом, который ведет к углублению разногласий и неравенства, с одной стороны, и нетолерантной репрессивной униформностью, с другой. Нам нужна такая интеграция, которая нас объединяет, не подавляя при этом» [Wood, Landry 2008: 62].

\section{ОМНИКУЛЬТУРАЛИЗМ И ПОЛИКУЛЬТУРАЛИЗМ: КОНЦЕПТЫ СБЛИЖЕНИЯ РАЗНЫХ КУЛЬТУР}

На волне критики мультикультурализма слева предлагаются новые модели организации межкультурных отношений, базирующиеся на признании существования в обществе этнических и прочих различий и ориентированные на поиск оснований для сближения представителей разных культур. Как это ни парадоксально, при обострении этнокультурных противоречий, спровоцированном миграционным кризисом в Европе, очертания оснований для такого сотрудничества там все же просматриваются [Цапенко, Монусова 2017]. Весной 2018 г. 77\% респондентов на территории ЕС считали, что у жителей их страны есть много общего. В Швеции этот показатель достигал $92 \%$, а в Ирландии - 96\%, и это несмотря на то, что они испытали в последние годы интенсивный приток мигрантов [Standard Eurobarometer 2018: 153]. Эта же тенденция просматривается и в Америке. 54\% опрошенных в 2016 г. испаноязычных и 57\% англосаксонских жителей США полагали, что для улучшения межрасовых отношений (в частности между белыми и черными) в этой стране важнее фокусироваться на общем, объединяющем этнические и расовые группы, а не на уникальности исторического опыта и характеристик разных групп [Pew... 2016: 34].

Иранский психолог Ф. Могхаддам продвигает модель омникультурализма. Ученый пишет: «Конечной целью омникультурализма является построение общества, в котором люди осознают общность человеческой природы и отдают ей приоритет, оставляя также место для признания и дальнейшего развития групповых отличий» [Moghaddam 2012: 306]. Фактически омникультуралистская модель предполагает конструирование своеобразной двойственной идентификации: с некой общностью как категорией высшего (superordinate) порядка и с локальной культурной группой. Инструментом реализации данного подхода

\footnotetext{
3 Запрет ношения знаков религиозной атрибутики мусульман (хиджабы, бурки) в общественных местах во Франции, Бельгии и Австрии, запрет строительства минаретов в Швейцарии и др.
} 
должна стать система образования, на первой стадии прививающая учащимся идеи общности человеческих ценностей и универсалий человеческого поведения, а на второй идентифицирующая групповые различия и подчеркивающая ценности разнообразия, но при этом отдающая приоритет общности людей.

Кросскультурные исследования в США указывают на поддержку идей омникультурализма немалой частью населения этой страны. Однако люди, конструируя универсалистский концепт человеческой природы как категорию высшего порядка, нередко склонны воспринимать именно свою группу как более прототипичную, что ведет к дискриминации других групп. Например, коренные жители Германии, идентифицируя себя одновременно как немцев и европейцев, стремятся исключать аутгруппы, в частности иммигрантов, из своего определения высшей - европейской - категории. Индикатором предубеждения человека по отношению к другим этносам может служить его мнение о том, что представители разных наций отличаются друг от друга врожденным уровнем интеллекта от рождения. В 2014 г. в Чехии, Португалии, Венгрии и Эстонии так считали более трети респондентов [European Social Survey... 2014]. И в США 29\% опрошенных в 2016 г. латинос отмечали, что окружающие относятся к ним как интеллектуально неполноценным [Pew... 2016: 61]. Некоторые сторонники омникультурализма полагают, что необходимо более широкое понятие человеческой природы, включающее ее понимание в других культурах и фокусирующееся на сходстве первичных человеческих эмоций [Bilewicz, Bilewicz 2012].

Историками Р. Келли и В. Прашадом предложена модель поликультурализма. В рамках этого подхода акцентируются исторические и современные взаимосвязи и взаимовлияния групп, относящихся к разным этносам, расам и культурам. Отмежевываясь от эссенциалистского рассмотрения культур как обособленных и неизменных, упомянутые авторы полагают, что не бывает «чистых» культур, присущих конкретным расовым или этническим группам, и что нельзя понимать и использовать культуру для разграничения, а фактически - разобщения групп. Они представляют культуры и народы как продукт пересекающихся историй и взаимосвязей между разными этническими и расовыми группами [Prashad 2003; Kelley 1999]. Примером таких взаимосвязей между народами Африки и Азии и взаимовлияний их культур считается боевое искусство кунг-фу, обретшее мировую популярность.

По замыслу архитекторов этой модели осознание людьми общности, характеризуемой как «все мы - наследники прошлого европейцев, африканцев, американских индейцев и ... азиатов» [Kelley 1999: 81], позволит улучшить их отношения с отличными «другими». Опираясь на результаты социально-психологических обследований населения, сторонники этого подхода считают, что распространение идей поликультурализма, в том числе через систему образования, поможет людям, относящимся к разным группам, улучшить отношения между ними, более комфортно чувствовать себя, живя, работая и обучаясь рядом с отличными «другими». При этом в процессе реализации такой политики не потребуется определение общих целей и формирование взаимозависимостей, поскольку культурное взаимовлияние существует и лишь нуждается в акцентировании [Rosenthal, Levy 2010]. 
Однако представители некоторых групп, особенно маргинальных, могут фокусироваться и на негативных аспектах таких связей, например, рабстве и колонизации, навязывании культуры господствующей группы и др. Представители доминирующих культур также могут недооценивать роль других культур. В 2014 г. как минимум 27\% коренных жителей европейских стран полагали, что одни культуры лучше других. А в Норвегии и Дании этот показатель зашкаливал за 60\% [European Social Survey... 2014].

При этом представление истории с позиции поликультурализма может фокусироваться на негативных межгрупповых отношениях и их влиянии на прошлое и современное состояние обществ, что чревато усилением взаимного неприятия и враждебности между такими группами. Напротив, сосредоточение внимания исключительно на позитивных взаимосвязях и взаимовлияниях, способствовавших, например, развитию знания, науки и технологий или формированию таких популярных продуктов культуры, как национальная еда, музыка, танцы и др., способно вызвать ощущение поверхностности данного подхода и его отвержение. Все это ограничивает потенциальные имплементационные возможности данной модели, как и предыдущей. Учитывая указанные обстоятельства, сторонники данной концепции считают предпочтительным ее нейтральный вариант, признающий наличие взаимосвязей без их оценки или же подчеркивающий как их позитивные, так и негативные аспекты [Bernardo, Rosenthal, Levy 2013].

Таким образом, эти культуралистские подходы не представляются самодостаточными. Более того, они могут иметь лишь отложенное во времени, ограниченное и притом далеко не всегда позитивное воздействие. Как представляется, общественному запросу на реформирование управления разнообразием гораздо больше отвечает интеркультурализм.

\section{ИНТЕРКУЛЬТУРАЛИЗМ КАК ВОЗМОЖНАЯ АЛЬТЕРНАТИВА ПРЕЖНИМ ПАРАДИГМАМ}

Интеркультурализм делает ставку на развитие культурного плюрализма и налаживание позитивного межкультурного взаимодействия между людьми на основе общности их потребностей и интересов независимо от их культурных принадлежностей в условиях их взаимной ответственности и равенства положения. В отличие от мультикультурализма, защищающего культурные различия, не создавая при этом условий для межэтнического и другого взаимодействия и сплочения социума, интеркультурализм обещает ослабить мотивы к формированию замкнутых культурных сообществ [Цапенко 2017].

Стержневые принципы этой модели были сформулированы на рубеже тысячелетий Л. Сэндеркок и вскоре получили развитие в работах П. Вуда, однако лишь в 2010-е годы, благодаря трудам Т. Кэнтла, Р. Сапаты-Барреро и ряда других исследователей, складывается теория интеркультурализма. Его идеи зафиксированы в Белой книге по межкультурному диалогу, утвержденной на Совете Европы в 2008 г., и в манифесте совместной программы Совета Европы и Европейской комиссии «Межкультурные города», принятом в 2009 г. 
В отличие от прежнего понятия диалога культур, исходящего из их различия, межкультурный диалог предполагает коммуникации поверх культурных границ. Как записано в «Белой книге», подобное межкультурное взаимодействие позволит «избежать разделения по этническому, религиозному, лингвистическому принципам», «...вместе идти вперед и на основе разделяемых всеми универсальных ценностей находить конструктивный и демократический подход к нашей различной идентичности» [White paper...2009: 3]. В результате должна сложиться «межкультурная система», которая возьмет лучшее из предыдущих моделей: из концепции ассимиляции - интерес к индивидуальной личности, ее правам и свободам, а у мультикультурализма - признание факта культурного многообразия и при этом включит «новый элемент - крайне важный для интеграции и социального сплочения - диалог на основе равного достоинства и общих ценностей» [White paper... 2009: 20]. Более того, сторонники интеркультурализма считают его новой парадигмой развития современных социумов и их интеграционной политики, представляющей третий путь, реальную альтернативу мультикультурализму и ассимиляции [Zapata-Barrero 2013; Cantle 2012; Bodirsky 2012]. Впрочем, о правоте столь категоричных суждений можно будет судить лишь по прошествии немалого времени.

В противовес мультикультурализму, сфокусированному на взаимоотношениях между государством и культурными меньшинствами, интеркультурализм акцентирует коммуникации между индивидами и группами. При этом подчеркивается добровольность подобного межкультурного взаимодействия. «Если люди не хотят контактировать, мы не может их к этому принудить», нельзя заставить их считать хорошей жизнь, изобилующую контактами с людьми других культур, и тем более сделать такое понимание публичной нормой [Zapata-Barrero 2017]. Интеркультурализм лишь стремится создать благоприятные условия и пространства для развертывания таких коммуникаций и интеграции диалога в образ жизни.

Основной площадкой для реализации идеи межкультурной интерактивности призваны стать города. В отличие от ориентации ассимиляционной и мультикультуралистской стратегий на национальный уровень, интеркультурализм сосредоточивается на локальном уровне. Хотя, как замечает канадский философ и политолог У. Кимлика, «локальные проекты межкультурного взаимодействия непременно будут хрупкими в отсутствие явного стремления государства переопределить понятие национальной общности» (цит. по: [Joppke 2018]).

Принципиально отличает интеркультурализм от мультикультурализма и лежащий в основе первого подход к разнообразию - не только и не столько как к фактору общественных антагонизмов, а как к ценности, преимуществу (diversity advantage), общественному благу и источнику развития креативного и инновационного потенциала общества.

Интеркультурализм отходит от свойственных мультикультурализму эссенциализма и принудительного группизма в отношении идентичностей. Он представляет людей и группы добровольными носителями динамичных многомерных и гибридных идентичностей, которые обладают более толерантным мышлением, способны видеть мир глазами «других», сквозь межкультурные линзы, фокусироваться на общее, сближающее, а 
не на различия, уважая при этом последние, адекватно переключать поведенческий репертуар. Это делает таких индивидов «идеальными медиаторами межкультурных конфликтов и разобщенности в сообществах, нациях и в мире в целом» [Benet-Martínez 2012: 639]. В выстраивании таких идентичностей видится потенциал преодоления на микроуровне антагонизмов «мы-чужие», социального сплочения, поддержания гражданского согласия и политической стабильности в многосоставных социумах [Cantle 2012: 103]. Этому благоприятствуют и идеологическая нейтральность, и кросс-партийность призывов интеркультурализма.

В отличие от мультикультурализма интеркультурализм имее четкую прагматическую направленность. По сути, это модель управления разнообразием в городских условиях, призванная развивать снизу (а не навязывать сверху) межкультурные коммуникации. Положения интеркультурализма уже получили воплощение в целом ряде европейских инициатив, тогда как омни- и поликультурализм пока носят лишь чисто теоретический характер. Наиболее резонансным стал совместный проект Европейской Комиссии и Совета Европы «Межкультурные города», инициированный в 2008 г. [Intercultural cities... 2009]. Помимо европейских в программе участвуют города Австралии, Израиля, Канады, Марокко, Мексики, США, Турции и Японии. Визитной карточкой этого проекта являются «Десять шагов (элементов) стратегии межкультурного города», которые включают:

- формирование позитивного отношения в обществе к разнообразию;

- пересмотр сквозь «межкультурные линзы» и соответствующая перестройка основных функций города в ключевых областях (образование, обустройство публичных пространств совместности, городское планирование и решение жилищных вопросов, деятельность городских служб, функционирование бизнеса и рынка труда, развитие культуры и спорта, работа полиции);

- посредничество и разрешение конфликтов;

- обучение языкам титульной нации и этнических меньшинств;

- сотрудничество городских органов власти с местными СМИ;

- развитие связей с другими городами и регионами мира;

- поддержание информированности о реальном состоянии дел в городе;

- развитие межкультурных навыков и компетенций;

- гостеприимство по отношению к новоприбывшим;

- межкультурное управление городом [Intercultural cities... 2009].

«Многие города экспериментируют с новой политикой и... являются естественными лабораториями, в которых может тестироваться такой подход» [Guidikova 2014: 1]. Менее чем за десятилетие существования программы «Межкультурные города» уже накоплен немалый арсенал позитивных практик, чувствительных к разнообразию, и отладка подобного инструментария продолжается.

Благодаря инициативам городов по созданию совместных публичных пространств, способствующих неформальным коммуникациям представителей разных культур, получили известность такие межкультурные практики, как «живые библиотеки», «вечера международной кухни», межэтнические семейные чаепития, футбольные матчи 
межэтнических команд и др. [Цапенко 2017]. Однако политика интеркультурализма не сводится лишь к таким «мягким» практикам, нередко выставляемым в качестве его витрины и все же имеющим второстепенное значение по сравнению с «жесткими» мерами структурной интеграции. Интеркультурализм предполагает настройку институтов рынка труда, образования, гражданства, политического участия и так далее на потребности разнообразного населения.

Данные проведенного в 2014 г. экспертного опроса координаторов межкультурных городов о результативности местной политики в сфере образования, культуры, спорта, политического участия и сплоченности сообществ свидетельствуют в целом о позитивной динамике в указанных областях (рисунок).

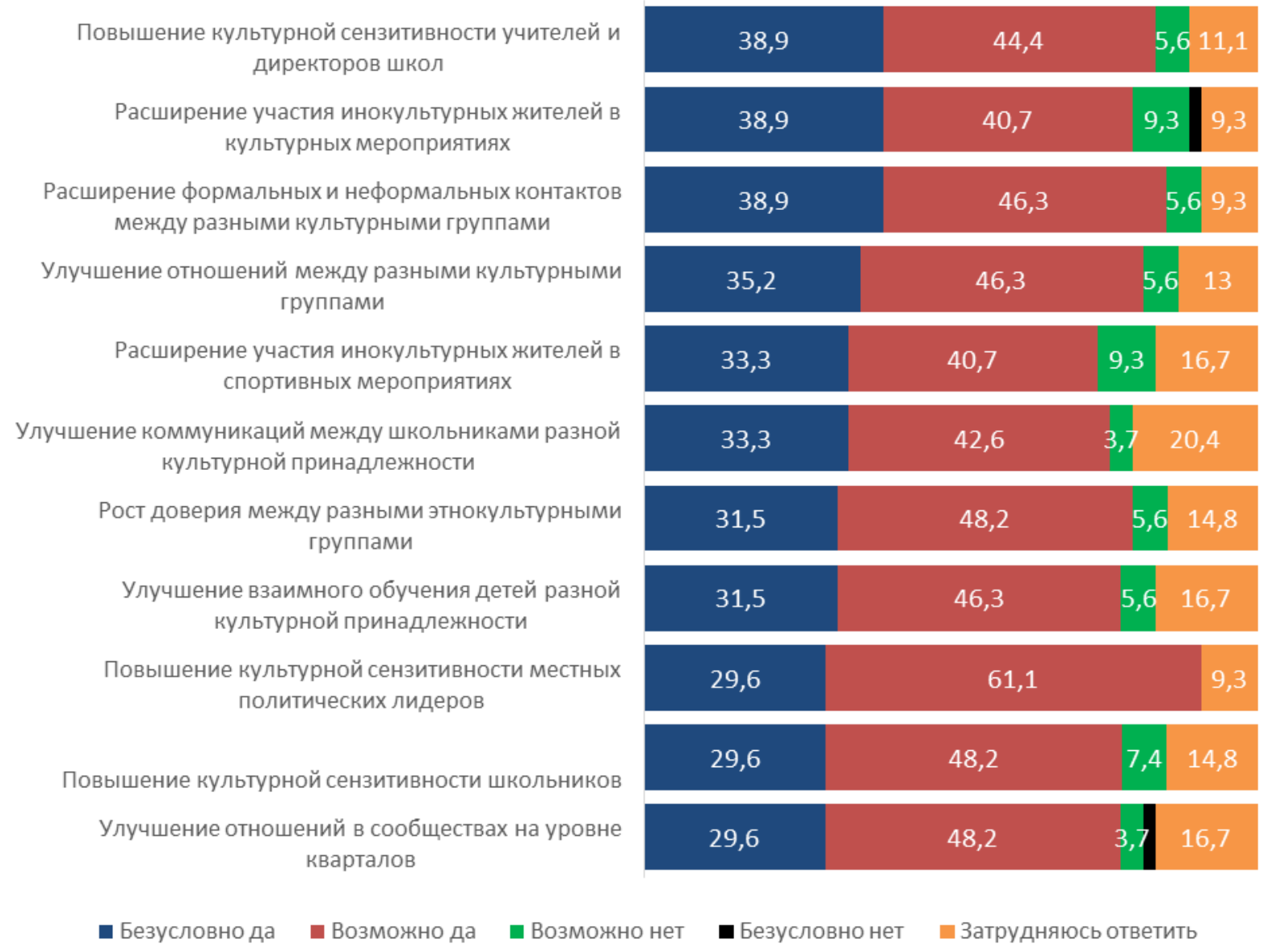

\section{Рисунок. Наличие позитивных эффектов межкультурных инициатив, \% респондентов, 2014}

Источник: Составлено по [Final Report... 2015: 46-48].

Другое осуществленное на статистических данных 2015-2016 гг. исследование обнаруживает тесную корреляцию между активной межкультурной инклюзивной политикой в городах, измеряемой «индикаторами открытости и межкультурности», с одной стороны, и благополучием местных жителей, а также их позитивной оценкой присутствия там иностранцев, с другой. Что в частности проявляется в большей доле указывающих на повышение безопасности жизни и шансов трудоустройства, качества государственных 
услуг и так далее по сравнению с не участвующими в программе городами [Joki, Wolffhardt 2018].

Хотя политика местных органов власти все четче вырисовывается как ключевой фактор успешной интеграции местных сообществ, приведенные данные свидетельствуют, что результаты реализации межкультурных инициатив в рамках проекта достаточно скромные. Пока не наблюдается существенного улучшения безопасности жизни, публичного имиджа разнообразия, активизации участия мигрантов и представителей меньшинств в принятии касающихся их решений, повышении успеваемости и снижении конфликтности в школах [Final Report... 2015: 46-48].

В проекте не уделяется особого внимания межрелигиозному диалогу. Между тем мусульманский вопрос - один из наиболее болезненных в европейских обществах. Он требует безотлагательного решения, которого не достичь без специальных пакетных мер. Отсутствие же их может поставить под удар всю программу. Поскольку в подобном эксперименте официально участвует лишь мизерно малая доля из общего массива городов Европы и других регионов мира (в конце 2018 г. всего 127 участников проекта, включая российский Ижевск), межкультурная политика имеет ограниченное, по сути анклавное распространение, что в свою очередь снижает ее устойчивость. Особенно в условиях современного всплеска этнополитической конфликтности в Европе, спровоцированного кризисом беженства и способного там не только застопорить, но и повернуть вспять интеграционный процесс.

В то же время число субъектов такой политики в рамках программы увеличивается. При этом подобные практики осуществляются и за пределами указанной программы. Проведенное ОЭСР в 2017-2018 гг. обследование 72 городов и муниципалитетов стран ЕС и Турции показало, что в $61 \%$ таких территориальных образований проводились кампании, популяризировавшие позитивные эффекты иммиграции, например, возрождение старых кварталов в Афинах, восполнение депопуляционных потерь в германской Альтене и так далее; в 47\% - практиковались консультации органов управления с городскими организациями мигрантов, гражданского общества и бизнес-структурами по интеграционным вопросам [Working Together... 2018: 33, 36]. В России, например, помимо Ижевска, имеется опыт налаживания неформальных межкультурных контактов на районном уровне Москвы ${ }^{4}$. Более того, политика интеркультурализма инкорпорирует и реконфигурирует сходные практики, которые уже сложились в предыдущие десятилетия в рамках прежних интеграционных подходов (например, предоставление иностранцам права участия в выборах местных органов власти, вовлечение представителей этнических меньшинств в деятельность правительственных институтов и государственных учреждений, проведение кампаний по борьбе с дискриминацией, осуществление специальных программ обучения детей иммигрантов языкам страны происхождения и

\footnotetext{
4 Установлено, что московские практики кулинарных мастер-классов для женщин, «живых библиотек» для школьников, интеркультурного футбола для молодых мужчин и другие привели к интенсификации общения с представителями других этносов, улучшению отношения к ним, усилению районной идентичности [Варшавер, Рочева, Иванова 2017].
} 
проживания, учет этнокультурной принадлежности пациентов при проведении их лечения и др.). Опора на такой фундамент усиливает позиции данного интеграционного курса.

Хотя, разумеется, частные локальные меры типа семейных чаепитий не воплотить на макроуровне, и конкретные практики, эффективные в одних условиях, не обязательно будут работать в другом контексте, тем не менее межкультурный подход применим и в более широком масштабе. Это в частности касается борьбы с предрассудками, расизмом и дискриминацией, усиления разнообразия персонала в организациях и стимулирования межкультурного взаимодействия внутри них, развития межкультурных компетенций и навыков государственных служащих и более широкого круга заинтересованных лиц, создания совместно используемых пространств (например, в СМИ и Интернете). О возможности воспроизведения такого опыта в масштабе регионов свидетельствует, в частности, принятие в целом ряде земель Германии интеграционных законов, которые требуют «межкультурной открытости органов власти», а именно внимательности к лингвистическим, религиозным и прочим культурным запросам обращающегося в них населения и даже приоритетности найма лиц с иммигрантскими корнями [Joppke 2018]. А в национальном плане - например, включение специального курса «межкультурная компетентность» в учебный план подготовки педагогических и социальных работников.

Расширению трансфера межкультурных технологий с местного на более высокий уровень призваны содействовать консультации органов власти соответствующих уровней и разные дискуссионные платформы (European Network of Intercultural Centres, EUROCITIES и др.). Этому должно поспособствовать и создание в 2017 г. Лаборатории инклюзивной интеграционной политики «Квадратура круга», которая будет заниматься разработкой концепции межкультурной политики национального и регионального масштаба.

\section{$* * *$}

В условиях кризиса ассимиляционизма и мультикультурализма, неспособных дать ответ на вызовы разнообразия, в принимающих обществах ведутся поиски новых оснований для сближения представителей разных культур. Выдвинуты такие концепты, как омникультурализм, акцентирующий общность человеческой природы, и поликультурализм, представляющий культуры и народы как продукт пересекающихся историй и взаимосвязей разных этнорасовых групп. Однако подобные подходы применимы в основном только в системе образования, и их реализация может дать лишь ограниченный и спорный эффект. Более адекватные теоретические и практические решения предлагает интеркультурализм, делающий ставку на перенастройку городской системы управления и общественных структур на условия разнообразия и налаживание снизу позитивного межкультурного взаимодействия.

Основные черты используемых и предлагаемых подходов представлены на схеме.

Межкультурные практики уже позитивно зарекомендовали себя в рамках европейского проекта на локальном уровне. Вместе с тем результаты таких инициатив пока скромны и непрочны. Неслучайно «Белая книга» предупреждает, что «межкультурный 
диалог не панацея от всех зол и не дает ответа на все возможные вопросы;.. сфера его применения может оказаться ограниченной» [White paper... 2009: 18]. В силу указанных обстоятельств перспективы интеркультурализма неопределенны и на данный момент не позволяют увидеть в нем реальную альтернативу прежним подходам, по крайней мере, пока он не пройдет проверку на национальном уровне. Чтобы представлять, как изменяется место интеркультурализма в общественном пространстве, необходимы его дальнейшие исследования как идейного течения и практической политики, причем в гораздо более широком, не ограничиваемом узкими рамками европейского проекта, контексте, равно как и отслеживание возможного появления новых парадигм управления разнообразием.

Схема. Основные подходы к социокультурной интеграции мигрантов

\begin{tabular}{|c|c|c|c|c|}
\hline Ассимиляционизм & $\begin{array}{c}\text { Мульти- } \\
\text { культурализм }\end{array}$ & $\begin{array}{c}\text { Омни- } \\
\text { культурализм }\end{array}$ & $\begin{array}{c}\text { Поли- } \\
\text { культурализм }\end{array}$ & $\begin{array}{c}\text { Интер- } \\
\text { культурализм }\end{array}$ \\
\hline$\downarrow$ & $\downarrow$ & $\downarrow$ & $\downarrow$ & $\downarrow$ \\
\hline \multicolumn{5}{|c|}{ Отношение к этнокультурным различиям и олицетворяющим их меньшинствам } \\
\hline$\downarrow$ & $\downarrow$ & $\downarrow$ & $\downarrow$ & $\downarrow$ \\
\hline $\begin{array}{c}\text { Игнорирование и } \\
\text { подавление }\end{array}$ & \multicolumn{4}{|c|}{ Признание и поддержание } \\
\hline$\downarrow$ & $\downarrow$ & $\downarrow$ & $\downarrow$ & $\downarrow$ \\
\hline \multicolumn{5}{|c|}{ Концептуальные основания интеграции и межкультурного взаимодействия } \\
\hline$\downarrow$ & $\downarrow$ & $\downarrow$ & $\downarrow$ & $\downarrow$ \\
\hline $\begin{array}{l}\text { Общность } \\
\text { принадлежности к } \\
\text { одной нации и } \\
\text { необходимость } \\
\text { принятия } \\
\text { господствующей } \\
\text { культуры }\end{array}$ & $\begin{array}{l}\text { Развитие культур и } \\
\text { взаимодействие } \\
\text { сообществ на } \\
\text { основе принципов } \\
\text { взаимности, } \\
\text { равенства, } \\
\text { сплочения, } \\
\text { уважения местных } \\
\text { правил }\end{array}$ & $\begin{array}{l}\text { Общность } \\
\text { человеческой } \\
\text { природы }\end{array}$ & $\begin{array}{l}\text { Общность } \\
\text { истории и } \\
\text { современные } \\
\text { взаимосвязи } \\
\text { этнорасовых } \\
\text { групп }\end{array}$ & $\begin{array}{l}\text { Общность } \\
\text { целей, } \\
\text { потребностей и } \\
\text { интересов } \\
\text { людей }\end{array}$ \\
\hline$\downarrow$ & $\downarrow$ & $\downarrow$ & $\downarrow$ & $\downarrow$ \\
\hline \multicolumn{5}{|c|}{ Механизмы практической реализации интеграционного подхода } \\
\hline$\downarrow$ & $\downarrow$ & $\downarrow$ & $\downarrow$ & $\downarrow$ \\
\hline $\begin{array}{l}\text { Ограничения на } \\
\text { проявление } \\
\text { инокультурной } \\
\text { принадлежности, } \\
\text { организация } \\
\text { обязательных } \\
\text { интеграционных } \\
\text { курсов }\end{array}$ & $\begin{array}{l}\text { Политико- } \\
\text { правовые и } \\
\text { экономические } \\
\text { меры поддержки } \\
\text { инокультурных } \\
\text { сообществ и их } \\
\text { организаций. } \\
\text { Политкорректность } \\
\text { и толерантность }\end{array}$ & $\begin{array}{l}\text { Привитие } \\
\text { учащимся } \\
\text { идей } \\
\text { общности } \\
\text { людей в } \\
\text { системе } \\
\text { образования }\end{array}$ & $\begin{array}{l}\text { Привитие } \\
\text { учащимся } \\
\text { идей } \\
\text { общности } \\
\text { людей в } \\
\text { системе } \\
\text { образования }\end{array}$ & $\begin{array}{l}\text { Межкультурный } \\
\text { диалог, учет } \\
\text { разнообразия в } \\
\text { деятельности } \\
\text { институтов } \\
\text { власти и т.п. }\end{array}$ \\
\hline
\end{tabular}

\section{ЛИТЕРАТУРА}

Андреева Л.А. (2018). Миграционные потоки «южных» христиан из стран Тропической Африки в секулярную Европу в начале XXI века: встреча «северного» и «южного» христианства // Контуры глобальных трансформаций. 11(4): 206-218.

Варшавер Е.А., А.Л. Рочева, Н.С. Иванова (2017). Интеграция мигрантов на местном уровне: результаты научно-практического проекта // Социологические исследования. 5: $110-117$. 
Культурная сложность современных наций (2016) / Отв. ред. В.А. Тишков, Е.И. Филиппова. М.: Политическая энциклопедия. 384 с.

Филиппова Е.И. (2014). Мультикультурализм мертв? Дискурс и практики мультикультурализма в России и за рубежом // Человек в меняющемся мире / Ред. кол. Д.А. Функ и др. Томск: Издательство Томского университета: 56-57.

Цапенко И. П., Г.А. Монусова (2017). Интеграционный потенциал этнокультурного разнообразия в европейских социумах// Polis. Political Studies. (4): 90-105.

Цапенко И.П. (2017). Интеркультурная парадигма интеграции мигрантов // Вестник Российской академии наук. 87(10): 915-926.

Benet-Martínez V. (2012). Multiculturalism: Cultural, social, and personality processes // Oxford Handbook of Personality and Social Psychology / K. Deaux, M. Snyder, eds. Oxford: Oxford University Press: 623-648.

Bernardo A., L. Rosenthal, S. Levy (2013). Polyculturalism and attitudes towards people from other countries // International Journal of Intercultural Relations. 37(3): 335-344.

Berry E., Epstein M. (2005). Transcultural experiments: Russian and American models of creative communication. New York: St. Martin's Press: 352.

Bilewicz M., A. Bilewicz (2012). Who defines humanity? Psychological and cultural obstacles to omniculturalism // Culture Psychology. 18(3): 331-344.

Bodirsky K. (2012). The intercultural alternative to multiculturalism and its limits. Paper presented at the EASA conference, Paris, 2012. URL:

http://scholarworks.umass.edu/chess_easa?utm_source=scholarworks.umass.edu\%2Fchess_e asa\%2F8\&utm_medium=PDF\&utm_campaign=PDFCoverPages (дата обращения: 10.09.2018).

Cantle T. (2012). Interculturalism: The new era of cohesion and diversity. London: Palgrave Macmillan. 256 p.

European Social Survey 2014 database (2014). Centre for Comparative Social Surveys, City University London, UK. URL: https://www.europeansocialsurvey.org (дата обращения: 29.08.2017).

Final Report Evaluation of the Intercultural Cities Programme. Council of Europe, 2015 (2015): 64. URL: https://rm.coe.int/CoERMPublicCommonSearchServices/DisplayDCTMContent?documentId $=0900001680307 \mathrm{e} 66$ (дата обращения: 15.09.2018).

Guidikova I. (2014). Cultural diversity and cities - the intercultural integration approach // RSCAS Policy Paper (2): 8. URL:

http://cadmus.eui.eu/bitstream/handle/1814/29358/RSCAS_PP_2014_02.pdf?sequence=1 (дата обращения: 19.10.2018).

Intercultural Cities: Towards a model for intercultural integration (2009) / P. Wood, ed. Strasbourg: Council of Europe. 124 p.

Joki A.-L., A. Wolffhardt (2018). How the intercultural integration approach leads to a better quality of life in diverse cities. URL: https://rm.coe.int/intercultural-to-the-core-how-theintercultural-cities-index-can-be-be/168076631b (дата обращения: 13.10.2018).

Joppke C. (2018) War of words: interculturalism v. multiculturalism // Comparative Migration Studies. 6: 11. URL: https://doi.org/10.1186/s40878-018-0079-1 (дата обращения: 19.10.2018). 
Kelley R. (1999). Polycultural Me // Utne Reader. 95. URL: http://www.utne.com/politics/thepeople-in-me.aspx?PageId=2 (дата обращения: 19.11.2017).

Lopez M., A. Gonzalez-Barrera, G. Lypez (2017). Hispanic identity fades across generations as immigrant connections fall away. URL: http://www.pewhispanic.org/2017/12/20/hispanicidentity-fades-across-generations-as-immigrant-connections-fall-away (дата обращения: 05.04.2018).

Moghaddam F.M. (2012). The omnicultural imperative // Culture and Psychology. 18: 304-330. URL: http://dx.doi.org/10.1177/1354067X12446230 (accessed:19.11.2017).

Pew Research Center (2016). On views of race and inequality, blacks and whites are worlds part. 2016. URL: http://assets.pewresearch.org/wp-

content/uploads/sites/3/2016/06/ST_2016.06.27_Race-Inequality-Final.pdf (accessed: 10.09.2018).

Pew Research Center (2017). Europe's growing Muslim population. URL: http://www.pewforum.org/2017/11/29/europes-growing-muslim-population (accessed: 10.09.2018).

Pew Research Center (2018). At least a million Sub-Saharan Africans moved to Europe since 2010. URL: http://assets.pewresearch.org/wpcontent/uploads/sites/2/2018/03/22135249/Africa-Migration-March-22-FULL-REPORT.pdf (accessed: 07.09.2018).

Prashad V. (2003). Bruce Lee and the anti-imperialism of Kung Fu: A polycultural adventure // Positions. 11(1): 51-89.

Rosenthal L., S. Levy (2010). The colorblind, multicultural, and polycultural ideological approaches to improving intergroup attitudes and relations // Social Issues and Policy Review. 4(1): 215-246.

Standard Eurobarometer 89 (2018). Public opinion in the European Union. Annex. 201 p. URL: http://ec.europa.eu/commfrontoffice/publicopinion/index.cfm (accessed: 10.10.2018).

Stepler R., M. Lopez (2016). U.S. Latino population growth and dispersion has slowed since onset of the Great Recession. URL: http://www.pewhispanic.org/2016/09/08/latinopopulation-growth-and-dispersion-has-slowed-since-the-onset-of-the-great-recession (accessed: 08.09.2018).

UN (2017). Trends in international migrant stock: The 2017 revision. URL: http://www.un.org/en/development/desa/population/migration/data/index.shtml (accessed: 22.08.2018).

Vertovec S. (2007). Super-diversity and its implications // Ethnic and Racial Studies. 30(6): 1024-1054.

Vespa J., D. Armstrong, L. Medina (2018). Demographic turning points for the United States: population projections for 2020 to 2060. Population estimates and projections. Current Population Reports. URL:

https://www.census.gov/content/dam/Census/library/publications/2018/demo/P25_1144.pdf (accessed: 10.10.2018).

Waal T. (2018). Is the post-multicultural era pro-diversity // Comparative Migration Studies.

6:15. URL: https://doi.org/10.1186/s40878-018-0084-4 (дата обращения: 10.10.2018).

White Paper on Intercultural Dialogue: "Living Together as Equals in Dignity" (2008).

Strasbourg: Council of Europe. 61 p. 
Wood P., C. Landry (2008). The Intercultural City: Planning for Diversity Advantage. London: Earthscan. 360 p.

Working Together for Local Integration of Migrants and Refugees (2018). Paris: OECD Publishing. $190 \mathrm{p}$.

Zapata-Barrero R. (2013). The three strands of intercultural policies: A comprehensive view // GRITIM-UPF Working Paper Series. 17: 37.

Zapata-Barrero R. (2017). Interculturalism in the post-multicultural debate: A defense // Comparative Migration Studies. 5: 14. URL: https://doi.org/10.1186/s40878-017-0057-z (дата обращения: 10.10.2018). 


\title{
FOR FRESH APPROACHES TO THE SOCIO-CULTURAL INTEGRATION OF MIGRANTS
}

\section{IRINA TSAPENKO}

\begin{abstract}
The article is devoted to an analysis of the main approaches taken by the global North States in their search for effective ways to manage cultural diversity. It is shown that mass immigration from the global South disrupts the cultural mix of host societies, thus presenting serious threats of erosion of their national identity, fragmentation and socio-political destabilization aggravated by the recent migration crisis. The threats of further expansion of predominantly Muslim areas and the strengthening of Islam's position in Europe are intertwined with the risks of a re-Christianization of this region by representatives of the southern currents of Christianity and the spread of archaic values and practices. The dominance in the US population of white Americans of European descent is being increasingly weakened by the rapidly growing communities of immigrants from Latin America and Asia with their foreign cultures. Neither assimilation, which ignores and suppresses cultural differences, nor the multiculturalism that has replaced it and both recognizes and promotes them, has been able to provide an effective response to the growth of diversity and to avoid the expansion of territorial segregation, cultural isolation of "parallel communities" and social dependency of their members. The assimilation approach is making a comeback on the wave of criticism of multiculturalism. At the same time, fresh integration concepts are being proposed. Omniculturalism emphasizes the commonality of human nature of different ethnic and racial groups, and polyculturalism - the intersection of their stories and relationships, but the practical implementation of both models can have only a limited and controversial effect. Interculturalism, which relies on the readjustment of the city's management system and social structures to the conditions of diversity and the establishment of constructive intercultural interaction from below, has already proven effective at a local level. However, the results of such initiatives are modest and fragile. This makes the prospects for interculturalism uncertain until it is tested at the national level.
\end{abstract}

Key words: immigration, ethnocultural diversity, assimilation, multiculturalism, new policies of civic integration, omniculturalism, polyculturalism, interculturalism.

\footnotetext{
Irina TsaPENKo (tsapenko@bk.ru), Primakov NATIONAL RESEARCH INSTITUTE OF WORLD ECONOMY AND INTERNATIONAL RELATIONS (IMEMO), RUSSIAN ACADEMY OF SCIENCES, RUSSIA.
}

\begin{abstract}
THIS ARTICLE WAS PREPARED WITH FINANCIAL SUPPORT PROVIDED BY THE RUSSIAN FOUNDATION FOR BASIC RESEARCH (RESEARCH GRANT № 16-07-OOOO8-OGON “INTEGRATION OF MIGRANTS WITH DiFFERENT CULTURAL BACKGROUND: PROSPECTS OF INTERCULTURALISM").
\end{abstract}

DATE RECEIVED : SEPTEMBER 2018.

\section{REFERENCES}

Andreeva L.A. (2018). Migratsionnyye potoki "yuzhnykh" khristian iz stran Tropicheskoy Afriki v sekulyarnuyu Evropu v nachale XXI veka: vstrecha "severnogo" i "yuzhnogo" khristianstva [Migration flows of "Southern" Christians from Tropical Africa to Secular Europe at the beginning of the XXI century: meeting of "Northern" and "Southern" Christianity // Kontury global'nykh transformatsiy [Contours of global transformations]. 11(4): 206-218.

Benet-Martínez V. (2012). Multiculturalism: Cultural, social, and personality processes // Oxford Handbook of Personality and Social Psychology / K. Deaux, M. Snyder, eds. Oxford: Oxford University Press: 623-648.

Bernardo A., L. Rosenthal, S. Levy (2013). Polyculturalism and attitudes towards people from other countries // International Journal of Intercultural Relations. 37(3): 335-344. 
Berry E., Epstein M. (2005). Transcultural Experiments: Russian and American Models of Creative Communication. New York: St. Martin's Press: 352.

Bilewicz M., A. Bilewicz (2012). Who defines humanity? Psychological and cultural obstacles to omniculturalism // Culture Psychology. 18(3): 331-344.

Bodirsky K. (2012). The Intercultural Alternative to Multiculturalism and its Limits. Paper presented at the EASA conference, Paris, 2012. URL:

http://scholarworks.umass.edu/chess_easa?utm_source=scholarworks.umass.edu\%2Fchess_e asa\%2F8\&utm_medium=PDF\&utm_campaign=PDFCoverPages (accessed: 10.09.2018).

Cantle T. (2012). Interculturalism: The New Era of Cohesion and Diversity. London: Palgrave Macmillan. $256 \mathrm{p}$.

European Social Survey 2014 database (2014). Centre for Comparative Social Surveys, City University London, UK. URL: https://www.europeansocialsurvey.org (accessed: 29.08.2017).

Filippova E.I. (2014). Mul'tikul'turalizm mertv? Diskurs i praktiki mul'tikul'turalizma v Rossii i za rubezhom [Multiculturalism is dead? Discourse and practices of multiculturalism in Russia and abroad] // Chelovek v menyayushchemsya mire [A person in a changing world] / D.A. Funk et al., eds. Tomsk: Izdatel'stvo Tomckogo universiteta: 56-57.

Final Report Evaluation of the Intercultural Cities Programme. Council of Europe, 2015 (2015): 64. URL:

https://rm.coe.int/CoERMPublicCommonSearchServices/DisplayDCTMContent?documentId $=0900001680307 \mathrm{e} 66$ (accessed: 15.09.2018).

Guidikova I. (2014). Cultural diversity and cities - the intercultural integration approach // RSCAS Policy Paper (2): 8. URL:

http://cadmus.eui.eu/bitstream/handle/1814/29358/RSCAS_PP_2014_02.pdf?sequence=1 (accessed: 19.10.2018).

Intercultural Cities: Towards a model for intercultural integration (2009) / P. Wood, ed. Strasbourg: Council of Europe. 124 p.

Joki A.-L., A. Wolffhardt (2018). How the intercultural integration approach leads to a better quality of life in diverse cities. URL: https://rm.coe.int/intercultural-to-the-core-how-theintercultural-cities-index-can-be-be/168076631b (accessed: 13.10.2018).

Joppke C. (2018) War of words: interculturalism v. multiculturalism // Comparative Migration Studies. 6: 11. URL: https://doi.org/10.1186/s40878-018-0079-1 (accessed: 19.10.2018).

Kelley R. (1999). Polycultural Me // Utne Reader. 95. URL: http://www.utne.com/politics/thepeople-in-me.aspx?PageId=2 (accessed: 19.11.2017).

Kul'turnaya slozhnost' sovremennykh natsiy [Cultural complexity of modern Nations] (2016) / V.A. Tishkov, E.I. Filippova, eds. Moscow: Politicheskaya entsiklopediya. 384 p.

Lopez M., A. Gonzalez-Barrera, G. Lypez (2017). Hispanic Identity Fades Across Generations As Immigrant Connections Fall Away. URL: http://www.pewhispanic.org/2017/12/20/hispanic-identity-fades-across-generations-asimmigrant-connections-fall-away (accessed: 05.04.2018).

Moghaddam F.M. (2012). The omnicultural imperative // Culture and Psychology. 18: 304-330. URL: http://dx.doi.org/10.1177/1354067X12446230 (accessed:19.11.2017).

Pew Research Center (2016). On views of race and inequality, blacks and whites are worlds part. 2016. URL: http://assets.pewresearch.org/wp- 
content/uploads/sites/3/2016/06/ST_2016.06.27_Race-Inequality-Final.pdf (accessed: 10.09.2018).

Pew Research Center (2017). Europe's growing Muslim population. URL: http://www.pewforum.org/2017/11/29/europes-growing-muslim-population (accessed: 10.09.2018).

Pew Research Center (2018). At least a million Sub-Saharan Africans moved to Europe since 2010. URL: http://assets.pewresearch.org/wpcontent/uploads/sites/2/2018/03/22135249/Africa-Migration-March-22-FULL-REPORT.pdf (accessed: 07.09.2018).

Prashad V. (2003). Bruce Lee and the anti-imperialism of Kung Fu: A polycultural adventure // Positions. 11(1): 51-89.

Rosenthal L., S. Levy (2010). The colorblind, multicultural, and polycultural ideological approaches to improving intergroup attitudes and relations // Social Issues and Policy Review. 4(1): 215--246.

Standard Eurobarometer 89 (2018). Public opinion in the European Union. Annex. 201 p. URL: http://ec.europa.eu/commfrontoffice/publicopinion/index.cfm (accessed: 10.10.2018).

Stepler R., M. Lopez (2016). U.S. Latino population growth and dispersion has slowed since onset of the Great Recession. URL: http://www.pewhispanic.org/2016/09/08/latinopopulation-growth-and-dispersion-has-slowed-since-the-onset-of-the-great-recession (accessed: 08.09.2018).

Tsapenko I.P. (2017). Intercultural paradigm of migrant integration // Herald of the Russian Academy of Sciences. 87(5): 454-463.

Tsapenko I.P., G.A. Monusova (2017). Integratsionnyy potentsial etnokul'turnogo raznoobraziya v evropeyskikh sotsiumakh [Integration potential of ethno-cultural diversity in European societies] // Polis. Political Studies. (4): 90-105.

UN (2017). Trends in international migrant stock: The 2017 revision. URL: http://www.un.org/en/development/desa/population/migration/data/index.shtml (accessed: 22.08.2018).

Varshaver E.A., A.L. Rocheva, N.S. Ivanova (2017). Integratsiya migrantov na mestnom urovne: rezul'taty nauchno-prakticheskogo proyekta [Integration of migrants at the local level: the results of the scientific and practical project] // Sotsiologicheskiye issledovaniya [Sociological Stusies]. 5: 110-117.

Vertovec S. (2007). Super-diversity and its implications // Ethnic and Racial Studies. 30(6): 1024-1054.

Vespa J., D. Armstrong, L. Medina (2018). Demographic turning points for the United States: population projections for 2020 to 2060. Population estimates and projections. Current Population Reports. URL:

https://www.census.gov/content/dam/Census/library/publications/2018/demo/P25_1144.pdf (accessed: 10.10.2018).

Waal T. (2018). Is the post-multicultural era pro-diversity // Comparative Migration Studies.

6:15. URL: https://doi.org/10.1186/s40878-018-0084-4 (accessed: 10.10.2018).

White Paper on Intercultural Dialogue: "Living Together as Equals in Dignity" (2008).

Strasbourg: Council of Europe. 61 p. 
Wood P., C. Landry (2008). The Intercultural City: Planning for Diversity Advantage. London: Earthscan. 360 p.

Working Together for Local Integration of Migrants and Refugees (2018). Paris: OECD Publishing. $190 \mathrm{p}$.

Zapata-Barrero R. (2013). The three strands of intercultural policies: A comprehensive view // GRITIM-UPF Working Paper Series. 17: 37.

Zapata-Barrero R. (2017). Interculturalism in the post-multicultural debate: A defense // Comparative Migration Studies. 5: 14. URL: https://doi.org/10.1186/s40878-017-0057-z (accessed: 10.10.2018). 